\title{
Eye movements and parafoveal processing during reading in Korean
}

\author{
Young-Suk Kim • Ralph Radach $・$ Christian Vorstius
}

Published online: 17 December 2011

(C) Springer Science+Business Media B.V. 2011

\begin{abstract}
Parafoveal word processing was examined during Korean reading. Twentyfour native speakers of Korean read sentences in two conditions while their eye movements were being monitored. The boundary paradigm (Rayner, 1975) was used to create a mismatch between characters displayed before and after an eye movement contingent display change. In the first condition, the critical previews were correct case markers in terms of syntactic category (e.g., object marker for an object noun) but with a phonologically incorrect form (e.g., using 를 instead of 을 when the preceding noun ends with a consonant). In the second condition, incorrect case markers in terms of syntactic category were used, creating a semantic mismatch between preview and target. Results include a small but significant parafovea-on-fovea effect on the preceding fixation, combined with a large effect on late measures of target word reading when a syntactically incorrect preview was presented. These results indicate that skilled Korean readers are quite sensitive to high-level linguistic information available in the parafovea.
\end{abstract}

Keywords Korean reading · Eye movements - Parafoveal preview · Syntactic processing $\cdot$ Semantic processing

\section{Introduction}

During the last two decades, eye movements have been used very successfully to study many aspects of reading. One of the shortcomings in this line of research has

Y.-S. Kim $(\bowtie) \cdot$ C. Vorstius

Florida State University and Florida Center for Reading Research, Florida State University,

1114 W. Call St., Tallahassee, FL 32306, USA

e-mail: ykim@fcrr.org

R. Radach

General and Biological Psychology, University of Wuppertal, Wuppertal, Germany

e-mail: radach@uni-wuppertal.de 
been that most of the work was focused on languages like English, German and French which use the Roman alphabetic writing system (Radach \& Kennedy, 2004). However, more recently, the field has started to close this gap, paying more attention to other languages and writing systems. A growing number of studies is focusing on Chinese, making it the prototypical alternative research environment, in which many of the issues are now being addressed that have been central to research in European languages. In contrast, only a few studies have looked at other writing systems, such as Hebrew, Japanese, Arabic or Thai.

A key issue that has recently been addressed in both English/German and Chinese is the parafoveal processing of semantic information. The acquisition of information from words to the right of the currently fixated position is a key feature of skilled reading. Work demonstrating such parafoveal preview typically uses the boundary paradigm (Rayner, 1975), where a previously masked target word is revealed after the eyes have crossed an invisible boundary just left of this target. The resulting increase in word viewing time serves as an indirect indicator of parafoveal processing benefit. Research into the nature of the information that can be acquired parafoveally has reliably demonstrated that readers obtain orthographic (e.g., Inhoff, 1990; Rayner, Well, Pollatsek, \& Bertera, 1982) and phonological information (e.g., Pollatsek, Lesch, Morris, \& Rayner, 1992), and that contextual constraint modulates parafoveal word processing (e.g., Balota, Pollatsek, \& Rayner, 1985).

With respect to the parafoveal extraction of semantic information, the predominant opinion has been negative, largely based on failures to empirically demonstrate such effects (Altarriba, Kambe, Pollatsek, \& Rayner, 2001; Rayner, Balota, \& Pollatsek, 1986). As an example, Rayner et al. used the boundary paradigm to present semantically related previews (tune-song) against conditions of a similar nonword (sorp-song), a nonrelated word (door-song) and an identical word baseline condition (song-song). They found facilitation from the visually similar nonword, but not from the semantically related preview (relative to the unrelated word condition). This finding is quite remarkable, given that the same stimuli produced a standard semantic priming effect in a parallel single word recognition experiment. The explanation provided for this discrepancy is that during sentence reading semantic information comes into play too late in the time course of word processing (see Rayner, White, Kambe, Miller, \& Liversedge, 2003, for a detailed discussion).

However, this view was recently challenged by Yan, Richter, Shu, and Kliegl, (2009) for the case of reading in Chinese. These authors obtained significant parafoveal preview effects on fixation and gaze duration for pictographic Chinese preview characters which were semantically related to targets. In addition, they also demonstrated a parafoveal-on-foveal effect on the duration of the last gaze before entering the target string. This line of research was further elaborated by Yan, Zhou, Shu, and Kliegl (in press) to include $\mathrm{N}+2$ word target words, so that the existence of semantic preprocessing within the (relatively small) perceptual span in Chinese reading appears well documented (see also Yan, Risse, Zhou, \& Kliegl, in press). More complex is the situation with respect to a similar attempt to demonstrate semantic preview effects in German. Hohenstein, Laubrock, and Kliegl (2010) used a combination of the boundary and fast priming paradigms, and showed that there 
was a semantic preview effect when the semantically related parafoveal word was available during the initial $125 \mathrm{~ms}$ of a fixation on the pretarget word. Their results suggest that, at least under favorable conditions, a parafoveal extraction of semantic information is also possible in alphabetic script.

The present paper reports an initial attempt to pursue the issue of high-level parafoveal processing in Korean, a language and writing system, in which, to our knowledge, this issue has never been studied before. Korean is an excellent candidate to address this research question because it uses case markers to signify syntactic functions of words (i.e., subject vs. object), immediately providing crucial semantic information about thematic roles (e.g., agent, recipient) within the sentence. While the different case markers carry morphosyntactic functions, different forms of markers per given case (e.g., subject or object) are used as a function of phonological context of preceding nouns. More generally, the Korean writing system is a hybrid between European languages and Chinese because Korean combines key features of both alphabetic and syllabic writing systems. This provides a unique opportunity to examine the influence of syntactic/semantic context versus phonological context in eye movement during reading in an orthography that is phonologically based (i.e., alphabetic) but presented in syllable blocks. Before we describe our research design in more detail, a brief overview of some key features of the Korean writing system is provided.

The Korean writing system, Hangul, was invented in the mid-fifteenth century (i.e., 1443) by King Sejong and his scholars as a means to increase the literacy rate for commoners. Before the invention of Hangul, the Chinese writing system (called Hanja) had been used for centuries. However, hanja did not match the Korean sound system and only privileged aristocrats (typically males) were able to master it. In modern Korea, Hangul is the official script of the Korean language while Hanja (Chinese script) is also used as a supplementary script. ${ }^{1}$ Contemporary Hangul has 14 basic consonant, 5 double consonant, 10 simple vowel, and 11 complex vowel letters (a total of 40). Hangul is an alpha-syllabary such that phonemes as well as syllables are visually represented and marked in the writing system. In other words, alphabet letters represent phonemes in a fairly consistent manner, and are organized into syllable blocks rather than a linear string of letters (Kim, Y.-S., 2011). For example, the five phonemes of a word /hakkyo/ (school) are represented in two syllable blocks, 학교, rather than a linear string of five letters, 하 ᄀᄀ 교. This syllabic representation reflects the saliency of the syllable in the Korean language. Hangul is similar to the Chinese or Japanese writing systems (both kanji or hiragana) in terms of its syllabary properties, but dissimilar from them in terms of its basic alphabetic nature (i.e., phonemes are represented by letters).

Unlike English, in Korean the morphosyntactic relation of a co-occurring element with other constituents of the sentence are indicated by case markers. ${ }^{2}$ These case markers provide critical morphosyntactic information for processing

\footnotetext{
${ }^{1}$ As an example, many newspapers use Hanja (Chinese characters) in parentheses for some homonyms to disambiguate the meanings in Korean.

2 There are approximately 47 markers in Korean such as delimiters and conjunctive particles (Kim, 1999). However, in the present study, we focused on frequently occurring case markers which mark the syntactic relation of a nominal element with co-occurring predicate or another nominal.
} 
words to clarify potential ambiguity. The Korean language is a left-branching or head final language with subject-object-verb as the prototypical order. Thus, important information carried by the verb comes at the end of a sentence. Furthermore, in Korean word order tends to be flexible although subject-object order occurs more frequently than the other way around. Thus, the fact that verbs occur at the end of a sentence combined with the flexibility in word order creates multiple ambiguity for processing basic facts (e.g., the meaning of nominals or nominal phrases) in a sentence, compared to a right-branching language such as English (Kim, Y., 1999).

This ambiguity for nominals or nominal phrases is clarified, signaled, and determined by case markers, which have no equivalents in many other languages such as English (Kim, Y., 1999; Lee \& Ramsey, 2000). Specifically, the subject of a sentence is marked by the use of a subject marker immediately following a subject noun or a noun phrase whereas in English the subject of a sentence is determined by word order. For instance, in the Korean sentence, 영희 윤아 때렸다 (Younghee Yuna hit), it is not clear who agent and recipient are and the sentence can be interpreted as either 'Younghee hit Yuna' or 'Yuna hit Younghee'. In this case, at least one case marker (either subject or object) is required after the pronouns to clarify the meaning. Thus, the case markers play a critical semantic function in Korean (Carlson \& Tanenhaus, 1988; Hagstrom \& Rhee, 1997; MacDonald, Perlmutter, \& Seidenberg, 1994). As postpositions, case markers follow a nominal or a nominal phrase or nominalized clause, and an adverb or adverbialized clause (Sohn, 1999). Such case markers include subject, object, and topical/contrastive markers. Topical makers denote topicality or contrast, and are typically translated as "as for" in English (see examples in "Appendix"; see Kim, Y., 1999 for a review of their grammatical and semantic function).

An important aspect of case markers in Korean which is critical to the present study is that a pair of case marker forms exist for subject, topical, and object cases, respectively. Different forms of case markers are obligatorily used in certain phonological contexts. The following are pairs of case markers: /I/ (이) and $/ \mathrm{ka} /$ (가)

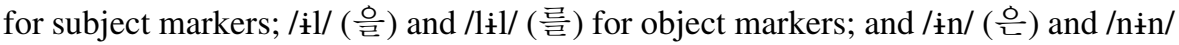
(는) for topical markers. Appropriate forms of markers are selected depending on the phonological environment of the immediately preceding word. The former ones (i.e., 이, 을, 은 $)^{3}$ in each pair are used when the preceding syllable ends with a consonant and the latter ones (i.e., 가, 를, 는) when the preceding syllable ends with a vowel. When the preceding syllable ends with a consonant, the selected markers start with vowels so that the consonant for the preceding syllable can be resyllabified into the following syllable. As an example, when the subject noun is /kuk/ (soup), the subject particle, /I/ 이 is used and resyllabified into /ku.kI/instead of /kuk.I/ (see Kim, Y.-S., 2007). The use of the other subject particle /ka/ is illegal. An example of using an object particle (or accusative) in a sentence is presented in Table 1, upper panel. In this sentence, an object particle, /liłl/를 (bold) indicates that

\footnotetext{
3 The letter, o, is a consonant letter and represents / $\mathrm{y} /$ phoneme in the coda position. However, in the onset position, it is a silent letter. Thus, the initial phoneme in case markers, 이, 을, 은, are all vowels /i/, $/ 1 /$, and $/ \mathrm{n} /$, respectively.
} 


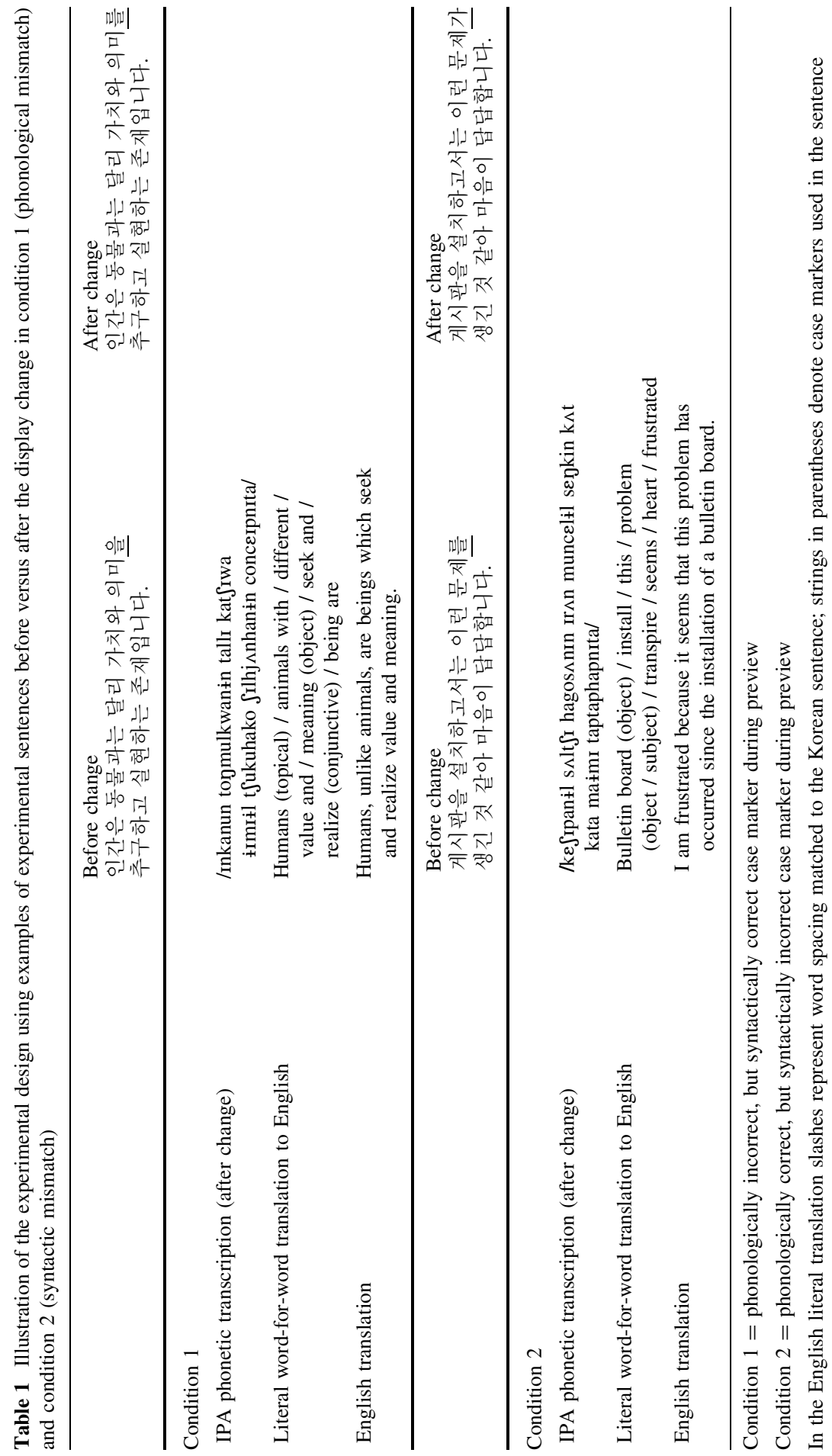


the immediately preceding noun ('value and meaning') functions as the object in the sentence. Furthermore, the immediately preceding noun, 'meaning,' is pronounced

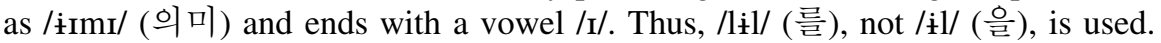

Previous studies have shown that Korean adults are sensitive to local grammatical cues signaled by case markers for syntactic processing (Kim, Y., 1999; Suh, 1994), and that Korean adult readers utilize incoming information such as case markers immediately attached to the nominal or nominal phrases for syntactic and sematic processing without delaying information processing until a verb is available (Kim, Y., 1999). However, there has so far been no research on whether processing is impeded when an incorrect phonological form of a case marker is used and how this would compare to the violation of using a syntactically (and semantically) incorrect case marker (e.g., a subject marker is used when an object marker is required). Thus, in the present study we examined the eye movements of proficient adult readers in Korean to investigate to what extent information provided by case markers is acquired parafoveally. To this end an invisible boundary was placed before a target word and display changes were implemented for half the experimental trials as soon as the eyes crossed this boundary. The extent of these changes was relatively modest as they only affected the case marker itself, which was always the third syllable (or character) of the target word.

Proficient readers in Korean were presented with two conditions. In the first condition, the critical previews were correct case markers in terms of syntactic category (e.g., object marker for an object noun) but with a phonologically incorrect form (e.g., using 를 instead of 을 when the preceding noun ends with a consonant). In the second condition, incorrect case markers in terms of syntactic category were used. For example, an object marker 를 was used instead of a subject marker 가 when the syntactic function of the noun was clearly that of a subject. The alternative, 를, meets the phonological condition for the preceding noun (i.e., ending in a vowel), but is incorrect for the syntactic function. Our rationale was that if skilled Korean readers can parafoveally preprocess the disambiguating syntactic (and semantic) information provided by case markers, the incorrect previews in condition 2 should lead to inflated viewing times on the target words. Since this type of discrepancy between preview and target may compromise the integration of word meaning on the sentence level, we hypothesized that effects may be substantial and materialize in late temporal measures such as total viewing time. In comparison, preview effects in condition 1, where previews are syntactically correct but phonologically incorrect, might result in less pronounced and/or short lived effects.

\section{Method}

\section{Participants}

Twenty-four native speakers of Korean were recruited from the Florida State University community. All participants had earned their bachelor's degree in Korea and the majority of the students were attending graduate schools and had been in the 
United States less than 5 years at the time of the study. One member of the sample was a visiting scholar who had been in the US for 5 months. All readers had normal or corrected-to-normal vision, and were given a general statement about the purpose of the study before their participation of the experiment (e.g., study of reading in Korean). More detailed debriefing information was provided after the experiment. Participants' age ranged from 26 to 45 .

\section{Apparatus and procedure}

The sentences were displayed, one at a time, in black on a light gray background using a 21 inch IIyama CRT monitor with a display resolution of 1,024 $\times 768$ pixels, running at $150 \mathrm{~Hz}$ refresh rate. Non-proportional Korean Batang-type font 14 point was used, and the viewing distance between each reader's eyes and the monitor was set to approximately $82 \mathrm{~cm}$. At this distance, each letter subtended $.5^{\circ}$ of visual angle laterally. Viewing was binocular but eye movements were recorded from the right eye only using an EyeLink 1000 eye tracking system (SR Research, Mississauga, ON, Canada) sampling at a rate of 1,000 Hz. Heads were positioned on a chin rest to minimize head movements. Relative accuracy of measurement was in the order of $.02^{\circ}$, absolute accuracy was maintained at $<1$ character width via calibration and validation routines (McConkie, 1981). Before trials began, the accuracy of the eye tracker was checked and recalibrated, if necessary. After each sentence, the participants were instructed to press a button to continue or to respond to questions.

\section{Materials and design}

A within subjects 2 (marker type) $\times 2$ (preview) design was used. A total of 60 target words were embedded in simple declarative sentences presented on a single line (see "Appendix" for a list of the stimuli with translations). These words had been selected from a corpus which includes the 5,000 most frequently used words in Korean adults' texts based on a total count of 25,585,960 tokens (Lee et al., 1991). Within conditions frequency of specific target words in the sentences is controlled because the same words were used for different forms of correct case markers (condition 1) and for incorrect case markers (condition 2). Comparing between conditions, the mean target word frequencies were almost identical, amounting to 443 per million ( $S D=337$, ranging from 63 to 1,626 ) in condition 1 and 442 per million $(\mathrm{SD}=286$, ranging from 178 to 1,331$)$ in condition $2(t=.02, P=.99)$. Target words were always two syllable nouns and target case markers were all monosyllabic. In Korean, the majority of nouns are two to three syllables (characters) long. Within the sample of sentences used in this study the maximum word length was 9 syllables and only about $5 \%$ of all words were longer than 5 syllables. ${ }^{4}$

Subject, topical, and object markers were used in conditions 1 and 2. In condition 1, each case marker included 10 items with an equal number of different

\footnotetext{
${ }_{4}$ The word length was counted based on spacing in Korean. Please see footnote 5 regarding spacing in Korean.
} 
phonological forms used before and after change. For instance, for the subject markers, 5 items changed from 가 $/ \mathrm{ka} /$ to 이 $/ \mathrm{I} /$, and 5 items from 이 $/ \mathrm{I} /$ to 가 $/ \mathrm{ka} /$. There were a total of 30 items. Condition 2 also had 30 items, and each case maker had 10 items, which were divided into 5 items of each phonological form. For example, for the topical maker, 5 items had 는 /nin/ after change and 5 items 은 /in/ after change. To implement each item, a unique sentence frame was constructed for each pair of (correct vs. parafoveally incorrect) case markers (see "Appendix" for a complete listing of sentences).

There were also 65 filler sentences, which reflect various syntactic structures in Korean. In addition, a total of 28 simple questions were presented, randomly distributed over the set of experimental and filler sentences. These questions ensured that reading for comprehension took place. The design included two factors, type of case markers (referred to as "condition"), and preview (correct vs. incorrect). In condition 1, an "incorrect preview" created a phonological mismatch between the case marker initially presented as the third syllable in the critical word and the adequate case maker, which was displayed after the right eye had crossed an invisible boundary just before the first pixel of the target region. Likewise, in condition 2, an "incorrect preview" created a syntactic (\& semantic) mismatch between the initially visible case marker and the one presented after the display change. Table 1 presents the item format with sentence frames that were used in both conditions of the experiment and also illustrates critical words displayed before and after a display change. None of the target words occupied the beginning or ending sentence positions. In sentences with display changes, the change occurred during the initial saccade into the target word (within 5-12 ms after crossing the invisible boundary) so that at the onset of the initial fixation the correct version of the marker was always implemented.

Data analysis

A word was considered fixated when a fixation fell on one of its constituent character (corresponding to a syllable) or the blank space preceding it. Fixation durations of less than $70 \mathrm{~ms}$ and of more than $1,000 \mathrm{~ms}$ were removed from analyses. In analyses of target words, deviations of fixation durations from the cell means of more than 3 SD were also eliminated. Excluded were also trials in which the first fixation on the target word was not preceded by a progressive saccade. Together with blinks or track losses, these restrictions resulted in the rejection of about $7.2 \%$ of all observations. In the analyses of these data, initial fixation durations were defined as the duration of the first fixation on the word, irrespective of whether the target word was subsequently refixated. Gaze durations included the time spent viewing the target during first pass reading, including the time spent refixating it, but excluding saccade durations. Total viewing time was the summed duration of all fixations made on the word. Saccade landing positions of incoming initial saccades were rounded to a tenth of a character before averaging; with the space preceding the target word coded as position .1-.9 (see Inhoff \& Radach, 1998; Inhoff \& Weger, 2003; Rayner, 1998, for discussions of oculomotor measures). Target word based eye movement parameters were subjected to mixed model analyses treating Subjects and Sentences as random effects. Condition, Preview, and 
the Condition $\times$ Preview Interaction were entered as fixed effects. Data analysis was carried out using SAS 9.0. Means and standard errors for all dependent variables are presented in Tables 2 and 3.

\section{Results}

Temporal parameters using all case markers

\section{Initial fixation duration}

There were no main effects of both factors on the duration of initial fixations on target words as the overall differences in mean were only $2 \mathrm{~ms}$ for condition $(F[1$, $1,238]=.06, P=.804)$ and $3 \mathrm{~ms}$ for Preview $(F[1,1,238]=.39, P=.532)$. However, the Condition $\times$ Preview interaction turned out to be significant $(F[1,1,238]=5.27$, $P=.022)$. Illegal preview had no significant effect in Condition 1, where parafoveal syntactic information was correct ( $8 \mathrm{~ms}$ difference, $t[1,238]=-1.19, P=.233$ ), but led to a significant $13 \mathrm{~ms}$ increase in initial fixation durations in Condition 2, where parafoveal syntactic information was incorrect $(t[1,238]=2.04, P=.0413)$.

\section{Gaze duration}

While there was no main effect for Condition $(1 \mathrm{~ms}, F[1,1,238]=.00, P=.969)$, both the main effect for Preview (13 ms, $F[1,1,238]=3.51, P=.061)$ and the Condition $\times$ Preview interaction $(F[1,1,238]=2.82, P=.093)$ approached significance. Apparently, both effects are mainly driven by Condition 2 (syntactic mismatch) with a substantial $25 \mathrm{~ms}$ effect for Preview $(t[1,238]=2.49, P=.013)$, but similar to initial fixation duration, no significant effect for Preview in Condition 1 $(1 \mathrm{~ms}, t[1,238]=.14, P=.889)$.

\section{Total reading time}

For total reading times the main effects for Condition showed a trend towards longer initial fixation durations in Condition $1(67 \mathrm{~ms}, F[1,1,238]=3.07, P=.079)$ and a significant effect for Preview $(31 \mathrm{~ms}, F[1,1,238]=4.53, P=.034)$ with longer initial fixation durations under illegal preview. The size of the preview effects amounted to $9 \mathrm{~ms}$ in Condition 1 and $52 \mathrm{~ms}$ in Condition 2 (see Table 2). Statistically, the Condition $\times$ Preview interaction was not significant $(F[1,1,238]=2.19, P=.139)$.

\section{Previous and next fixation duration}

For previous fixation durations there were significant main effects for Condition $(12 \mathrm{~ms}, F[1,1,238]=4.07, P=.044)$ and Preview $(10 \mathrm{~ms}, F[1,1,238]=4.66$, $P=.031)$. Illegal previews increased the duration of the preceding fixation by $12 \mathrm{~ms}$ when the mismatch was phonological (condition 1) and by $8 \mathrm{~ms}$ when it was syntactic (condition 2). Again, the Condition $\times$ Preview interaction was not 


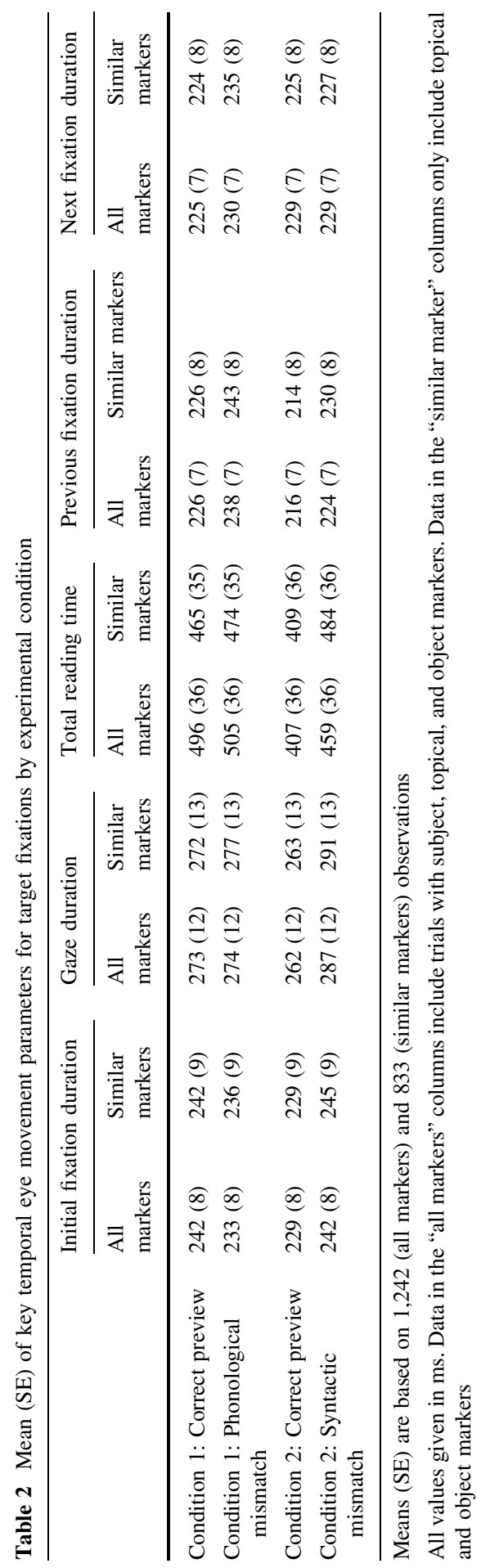


Table 3 Mean (SE) of key spatial parameters and fixation probabilities on target words

\begin{tabular}{|c|c|c|c|c|c|c|c|c|}
\hline & \multicolumn{2}{|c|}{$\begin{array}{l}\text { Fixation } \\
\text { probability }\end{array}$} & \multicolumn{2}{|c|}{$\begin{array}{l}\text { Refixation } \\
\text { probablitity }\end{array}$} & \multicolumn{2}{|c|}{$\begin{array}{l}\text { Initial landing } \\
\text { position }\end{array}$} & \multicolumn{2}{|c|}{$\begin{array}{l}\text { Incoming saccade } \\
\text { amplitude }\end{array}$} \\
\hline & $\begin{array}{l}\text { All } \\
\text { markers }\end{array}$ & $\begin{array}{l}\text { Similar } \\
\text { markers }\end{array}$ & $\begin{array}{l}\text { All } \\
\text { markers }\end{array}$ & $\begin{array}{l}\text { Similar } \\
\text { markers }\end{array}$ & $\begin{array}{l}\text { All } \\
\text { markers }\end{array}$ & $\begin{array}{l}\text { Similar } \\
\text { markers }\end{array}$ & $\begin{array}{l}\text { All } \\
\text { markers }\end{array}$ & $\begin{array}{l}\text { Similar } \\
\text { markers }\end{array}$ \\
\hline $\begin{array}{c}\text { Condition 1: } \\
\text { Correct } \\
\text { preview }\end{array}$ & $.95(.01)$ & $.95(.01)$ & $.13(.02)$ & $.14(.02)$ & $1.44(.08)$ & $1.94(.08)$ & $6.98(.43)$ & $6.71(.53)$ \\
\hline $\begin{array}{l}\text { Condition 1: } \\
\text { Phonological } \\
\text { mismatch }\end{array}$ & $.96(.02)$ & $.96(.02)$ & $.21(.02)$ & $.20(.03)$ & $1.39(.08)$ & $1.90(.08)$ & $6.80(.56)$ & $6.33(.53)$ \\
\hline $\begin{array}{c}\text { Condition 2: } \\
\text { Correct } \\
\text { preview }\end{array}$ & $.95(.01)$ & $.98(.02)$ & $.15(.02)$ & $.16(.03)$ & $1.42(.06)$ & $1.90(.08)$ & $7.27(.59)$ & $7.10(.53)$ \\
\hline $\begin{array}{c}\text { Condition 2: } \\
\text { Syntactic } \\
\text { mismatch }\end{array}$ & $.94(.01)$ & $.95(.01)$ & $.19(.02)$ & $.20(.03)$ & $1.37(.05)$ & $1.84(.08)$ & $6.81(.47)$ & $6.74(.53)$ \\
\hline
\end{tabular}

Means (SE) are based on 1,242 (all markers) and 833 (similar markers) observations

Initial landing position and incoming saccade amplitude are given in character (syllable) units. Data in the "all markers" columns include trials with subject, topical, and object markers. Data in the "similar marker" columns only include topical and object markers

significant $(F[1,1,238]=.11, P=.741)$. There were no significant main effects or interactions for next fixation durations (all $F \mathrm{~s}<1$ ), indicating that effects did not spill over to immediately following fixations.

Fixation probabilities and spatial parameters using all case markers

\section{Fixation probability}

Given the fact that fixation probability ranged from .94 to .96 for the cells of our experimental design (see Table 3), it is likely that a ceiling effect prevented any significant influence of condition or preview on fixation probability (all $F_{\mathrm{S}}<1$ ).

\section{Refixation probability}

The effect pattern for refixation probability was similar to the one reported above for gaze duration. Refixations were not affected by Condition $(F[1,1,238]=.00$, $P=.971)$, but showed a significant main effect for Preview $(F[1,1,238]=7.82$, $P=.005)$, with higher refixation probabilities in the illegal (.196) compared to the legal preview condition (.141). There was no significant interaction $(F[1,1,238]=$ $.57, P=.451)$. Incoming progressive saccade amplitudes and landing positions were not affected by any factor (all $F \mathrm{~s}<1$ ).

It could be argued that some of our results, especially the parafovea-on-fovea effect on the preceding fixation duration is primarily driven by visual or orthographic dissimilarity between preview and target word. However, it should be kept in mind that 
the present experiment manipulated only the last of three characters (syllables) within each of the target words. Looking at our case marker pairs (see "Appendix"), it is clear that most of the pairs used in the present work are quite similar, when, for example, the

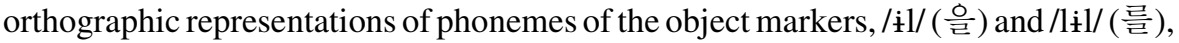
and topical markers, /in/ (은) and /nin/ (는) share at least two phonemes and their corresponding graphemes, respectively. However, there is one exception, the subject case markers /I/ (이) and $/ \mathrm{ka}$ / (가) that have distinctive phonological and thus orthographic forms. To address this potential source of variance, we eliminated the items involving the subject case markers $/ \mathrm{I} /$ (이) and $/ \mathrm{ka} /$ (가), reducing the number of sentences per condition from 30 to 20 . All of the analyses reported above were repeated with this reduced item pool and the results are also presented in Tables 2 and 3. Rather than weakening the observed effects, a very similar pattern of results emerged in these supplementary analyses.

Temporal parameters using orthographically similar case markers

\section{Initial fixation duration}

For the reduced sample of items, there were again no main effects for Condition ( $3 \mathrm{~ms}$, $F[1,829,829]=.10, P=.757)$ or Preview $(5 \mathrm{~ms}, F[1,829,829]=.65, P=.423)$. The Condition $\times$ Preview interaction was close to significance $(F[1,829]=3.72$, $P=.054)$. Illegal preview had no significant effect in Condition 1, where parafoveal syntactic information was correct, $(6 \mathrm{~ms}, t[829]=-.80, P=.423)$, but led to significantly longer initial fixation durations in Condition 2, where parafoveal syntactic information was incorrect $(15 \mathrm{~ms}, t[829]=1.91, P=.056)$.

\section{Gaze duration}

For trials with similar case markers the gaze duration results pattern was also replicated. There was no main effect for Condition $(1 \mathrm{~ms}, F[1,829]=.04$, $P=.835)$, but the main effect for Preview $(17 \mathrm{~ms}, F[1,829]=4.07, P=.044)$ reached significance. The Condition $\times$ Preview interaction $(F[1,829]=2.09$, $P=.149)$ did not reach significance, but data show the identical pattern-i.e., effects are mainly driven by Condition 2 (syntactic mismatch) with a $29 \mathrm{~ms}$ effect for Preview $(t[829]=2.43, P=.016)$, but there was no significant effect for Preview in Condition 1 (5 ms, $t[829]=.41, P=.683)$.

\section{Total reading time}

For total reading times the main effects for Condition $(23 \mathrm{~ms}, F[1,829]=.38$, $P=.539)$ did no longer show a trend towards significance in trials with similar markers. However, the main effect for Preview is more pronounced (41 ms, $F[1,829]=6.71, P=.009)$ and the Condition $\times$ Preview interaction also reached significance $(F[1,829]=4.02, P=.041)$. Again, this interaction is driven by Condition $2(74 \mathrm{~ms}, t[829]=3.25, P=.001)$ whereas there was no significant effect of Preview in Condition 1 (9 ms, $t$ [829] $=.39, P=.698)$. 


\section{Previous and next fixation duration}

In the reduced item pool including trials with visually similar case markers (i.e., object and topical) there was a trend towards longer preceding fixation durations in Condition 1 (13 ms, $F[1,829]=2.95, P=.086)$. The Preview effect is more pronounced $(17 \mathrm{~ms}, F[1,829]=8.62, P=.003)$ and the Condition $\times$ Preview interaction was again not significant $(F[1,829]=.01, P=.921)$. Illegal previews increased the duration of the preceding fixation by $17 \mathrm{~ms}$ when the mismatch was phonological (condition 1) and by $16 \mathrm{~ms}$ when it was syntactic (condition 2 ). There were no significant main effects or interactions for next fixation durations (all $F \mathrm{~s}<1$ ).

Fixation probabilities and spatial parameters using orthographically similar case markers

\section{Fixation probability}

Again, the probabilities of fixating a target ranged from .95 to .98 , perhaps creating a ceiling that prevented any significant effects (all $F \mathrm{~s}<1$ ).

\section{Refixation probability}

The probability of refixating a target word was not affected by Condition $(F[1,829]=.00, P=.845)$, but showed a significant main effect for Preview $(F[1,829]=5.58, P=.018)$, with higher refixation probabilities in the illegal $(.20)$ compared to the legal preview condition (.15). There was no significant interaction $(F[1,829]=.13, P=.714)$. Again, in the reduced item pool including only sentences with visually similar case markers, there were no significant effects on incoming saccade amplitude or initial landing position or (all $F \mathrm{~s}<1)$.

\section{Discussion}

The present study provided a clear cut and interesting pattern of results. First, for both conditions there was an early effect manifesting itself in a small but significant increase in the duration of the fixation made before entering the target word. This finding is in line with recent reports on semantic parafoveal-on-foveal effects in Chinese (Yan, Richter, Shu, \& Kliegl, 2009; Yan, Zhou, Shu, \& Kliegl, in press; Yan, Risse, Zhou, \& Kliegl, this volume; Yang, Wang, Tong, \& Rayner, in press), adding evidence from the Korean writing system to the ongoing debate about a more sequential versus parallel nature of word processing in skilled reading. As part of this debate, it has been argued that parafoveal-to-foveal effects can be attributed to mislocated fixations based on saccades that were aimed at word $\mathrm{N}+1$, but, as a result of saccadic undershoot, actually landed on word N (Rayner, White, Kambe, Miller, \& Liversedge, 2003). To address this concern, we repeated the analysis of the durations of fixations prior to entering the target word with all cases where saccade launch sites had been further away than two (syllabic) characters. This selection eliminated $41.5 \%$ 
of all observations, which is considerably more than any reasonably estimated percentage of potential undershoot cases (Engbert \& Nuthmann, 2008). It is also likely to be more than what were considered far launches by Drieghe, Rayner, and Pollatsek (2008), who considered three or fewer alphabetic characters from the beginning of an English word to be a near saccade launch distance.

Looking at the subset of data with far launch sites, incorrect previews increased the duration of the preceding fixation by $27 \mathrm{~ms}$ when the mismatch was phonological (condition 1) and by $10 \mathrm{~ms}$ when it was syntactic (condition 2). These effects were numerically larger than the values we have reported above for the full data set so that the overall Preview effect turned out to be slightly more pronounced $(18 \mathrm{~ms}$, $F[1,687]=9.76, P=.002)$. There was a trend towards longer preceding fixation durations in Condition $1(14 \mathrm{~ms}, F[1,687]=3.65, P=.056)$, while the Condition $\times$ Preview interaction was again not significant $(F[1,687]=2.14, P=.144)$. These data effectively rule out an explanation of the parafovea-on-fovea effect based on mislocated fixations.

It is quite remarkable that this early effect materialized in both case marker type conditions, as these conditions represent different aspects of target word processing. In condition 1, the case marker used as the critical preview was syntactically correct but incompatible with the phonological context established by the preceding word. In condition 2, however, the marker used as a parafoveal preview was phonologically correct but did not fit with the syntactic function of the target noun in the sentence. Considering the phonological mismatch condition, it could have been the case that the articulatory characteristics of the pretarget word were available early enough to establish constraints on the nature of the correct parafoveal case marker, creating a mismatch that in turn caused the observed increase in pretarget fixation duration (see e.g., Lee, Rayner, \& Pollatsek, 1999, for evidence on the time course of phonological processing in continuous reading in English). However, this interpretation appears unlikely, as the parafoveal-on-fovea effect was as strong in Condition 2, where the preview was phonologically correct.

Another approach to interpreting the parafovea-on-fovea effect on prior fixation duration would be in terms of visual similarity between previews and target words. As indicated above, most of the pairs used in the present work are quite similar, as in the case of the object markers, / $\mathbf{1} 1 /$ (을) and /liłl/ (를), and topical markers, /ín/ (은) and /nin/ (는) which share at least two phonemes and their corresponding graphemes. When the items with more visual dissimilarity between preview and target (i.e., the subject markers $/ \mathrm{I} /$ 이 and $/ \mathrm{ka}$ / 가) were eliminated from the pool of sentences, virtually the same pattern of effects emerged. In the critical condition 2 with a syntactic mismatch between preview and target, the size of the parafoveaon-fovea effect even increased from 8 to $16 \mathrm{~ms}$.

Future studies should incorporate visual and/or orthographic similarity between pairs of case markers as a factor to determine whether the observed early parafoveal-on-foveal effect may also be mediated to some extent by low-level distinctiveness, rather than being exclusively based on syntactic/semantic or phonological appropriateness of what was visible in the parafovea. It should be emphasized, however, that there is no doubt that the parafovea-on-fovea effect 
obtained in this study is cognitive rather than visual in nature, as all previews constituted regular Korean words.

The second, and much stronger, effect obtained in the present work manifested itself in the target gaze duration and total reading time in condition 2 . In line with our hypothesis, there was a $24 \mathrm{~ms}$ increase in gaze duration, when there was a syntactic mismatch between preview and target, while in condition 1, where the preview was syntactically (and semantically) correct, gaze durations were virtually identical. The syntactic discrepancy effect increased to $50 \mathrm{~ms}$ in total viewing time, indicating that the parafoveal acquisition of inappropriate syntactic case marker information led to a substantial amount of target word re-reading. This finding points to difficulty with the integration of meaning on the sentence level as the main locus of the effect. As noted earlier, case markers in Korean provide critical semantic information about the meaning and role of nominals. Critically, because syntactic functions of nominals are not determined by word order, the readers' meaning construction processes cannot be completed until the reader has identified case markers. It should be noted that this mechanism of utilizing parafoveal information for sentence-level construction of meaning goes beyond the recent reports of semantic preprocessing in Chinese reading, where semantic processing was focused on word meanings (Yan, Richter, Shu, \& Kliegl, 2009; Yan, Zhou, Shu, \& Kliegl, in press; Yan, Risse, Zhou, \& Kliegl, in press).

On a more global level, the finding in the present study might provide some insights into discrepant findings between studies with readers of Roman alphabet letters and studies with Chinese readers, given that the Korean writing system has characteristics of both-alphabetic and syllabic in orthographic representation. Studies with Roman alphabet writing systems have generally provided no evidence for semantic processing (but see Hohenstein et al., 2010, for an exception) whereas studies with Chinese readers have (e.g., Yan et al., 2009, in press; Yang et al., in press). Since these two writing systems are vastly different in many aspects, it is difficult to identify the causes of contradictive findings. Suggested explanations for the sematic preview effect found in Chinese point towards characteristics of the Chinese writing system. For instance, Chinese has a syllabic (and morphemic) representation of characters compared to the linear grapheme representation of Roman alphabetic writing systems and therefore contains more dense information which may be easier to acquire from locations to the right of fixation within the perceptual span (Yang et al., in press). Moreover, the Chinese characters are meaning-based rather than phonology-based. Finally, it has been suggested that meaning processing might be more critical for word recognition in Chinese because characters, not words, are the visually distinctive units and thus, readers are required to rely on context and information from the right of fixation to determine whether a character is a word or part of a word as a morpheme (Yang et al., in press; see also Liu, Inhoff, Ye, \& Wu, 2002; Yen, Tzeng, Radach, \& Tsai, 2011).

Korean has a syllabic writing system like Chinese but unlike Chinese, it is also alphabetic (thus called alphasyllabary). Given the existing similarities and differences, the preview effects found in the present study may be attributed to forces operating on two levels, one related to the orthographic characteristics implemented in the Hangul writing system and the other deeply rooted in structural 
characteristics. The critical structural feature is the left-branching nature of the Korean language. Left-branching or head-final languages such as Turkish, Japanese, Tamil, Basque and Korean tend to place dependents before head words (e.g., direct objects before verbs) and information critical for meaning processing is often delayed. As a matter of principle, "the amount and the type of left-ward embedding" allowed is endless (Mazuka \& Lust, 1990, p. 168) so that clause boundaries as well as processing of many words within a sentence may remain highly uncertain (Koh, 1997). Therefore, there is a high demand for spatially distributed (parafoveal) processing, as any source of disambiguating information such as case markers, connectives, or verbs (all located at the end of the respective nominals, clauses, or sentences) must be accessed as quickly as possible to clarify meanings on the word and sentence level.

Looking at the level of orthographic characteristics, it appears that the designers of the Hangul writing system attempted to tackle the problem we have just described. A dedicated character is attached to a noun just for the purpose of resolving the semantic ambiguity of case role assignment via the immediate assignment of a syntactic class. Since case marking characters are located at the rightward edge of the word, spatially distributed (presumably parallel) character processing becomes critical for access to full word meaning. The compact format of syllable block characters in Hangul are particularly well suited to accommodate this demand, based on high information density within a relatively small spatial region. At the same time, word boundaries are clearly marked ${ }^{5}$ so that resources needed for parafoveal word segmentation in reading Chinese or Thai are available for spatially distributed processing on the syntactic and semantic level.

Taken together, the results obtained in this study suggest that Korean readers are quite sensitive to high-level linguistic information in the parafovea. From a psycholinguistic point of view it makes perfect sense to place high importance on the immediate processing of case marking characters, given their role for the assignment of meaning (e.g., thematic roles) in Korean sentence processing. At the same time the high density of information in the unique syllable block structure of Korean script provides favorable conditions for parallel letter and word processing within a relatively limited perceptual span. More research will be needed to determine whether the case of high-level parafoveal preview effect we have identified in this study represents the rule also for other types of spatially distributed word processing in Korean. It will also be interesting to see whether our findings can be generalized to the Japanese (Hiragana) writing system, where a similar kind of case marking is used to process sentence structure (e.g., Uehara, 1997).

Looking at the future development of theories and computational models for reading in Korean, the question arises which of the available modeling architectures will provide the best environment for this task (see Radach, Reilly, \& Inhoff, 2007;

\footnotetext{
5 Spacing in Korean does not correspond to word boundaries found in English or other European languages. Instead, spacing is placed between meaning units more or less. For instance, in a sentence 영희가 학교에 갑니다 (Younghee is going to school), spaces are found after Younghee with a subject marker (영희가), after a prepositional phrase (to the school, 학교), and after verb phrase (is going, 갑니다). Please see Lee and Ramsey (2000) for further discussion on spacing and word boundary in English and Korean.
} 
Reichle, Rayner, \& Pollatsek, 2003, for detailed discussions). While it seems feasible to develop a model of reading in Korean within both sequential (Reichle, Pollatsek, Fisher, \& Rayner, 1998) and processing gradient (Engbert, Nuthmann, Richter, \& Kliegl, 2005; Reilly \& Radach, 2006) frameworks, we believe that the observed high-level preview effects will be most parsimoniously accounted for within a model that allows for some degree of parallel word processing across the perceptual span.

\section{Appendix: Sentences used in the experiment}

The parts given in bold are the critical case markers manipulated in this study, which are always the third character (and syllable) of the target word. The markers before a slash represent incorrect previews, whereas the ones after the slash are the correct markers as they were presented after implementing the display change. Each sentence is presented in Korean, followed by literal word-by-word translation in English, and more natural translation in English.

Sentences used in condition 1

텔레비전을 보면서 동생이 사과을/를 껍질채 맛있게 먹었습니다.

Television / watch while / little brother / apple (object) / skin with / deliciously / ate.

$\rightarrow$ My little brother ate an apple deliciously, even including its skin, (or enjoyed an apple) while watching TV.

인간은 동물과는 달리 가치와 의미을/를 추구하고 실현하는 존재입니다.

Humans / animals with / different / value and / meaning (object) / seek and / realize / being are.

$\rightarrow$ Humans, unlike animals, seek and realize value and meaning.

휘파람새는 명쾌하고 아름다운 소리을/를 내는 명창 중의 명창새입니다.

A bush warbler / clear and / beautiful / sound (object) / master singer / among / master singer bird is.

$\rightarrow$ A bush warbler is one of the master singing birds which produce clear and beautiful sounds.

지난 주에 전시된 그림의 제목은 자유을를 찾아 가는 사람들이었습니다. Last / week / displayed / painting's / title / freedom (object) / seek / going / people was.

$\rightarrow$ The title of the displayed painting last week was people seeking freedom (freedom seekers).

이 시간에는 신년기획 특집으로 경제을/를 회복시킨 분들에 관해 논의하겠습 니다.

This / hour at / new year / project / special for / economy (object) / recover / people / about / discuss will. 
$\rightarrow$ As a new year special, at this hour we will discuss people who contributed to the recovery of our economy.

도도한 이미지를 자랑하던 사람이 눈물를/을 글썽이며 말을 이었습니다. Arrogant / image / boast / person / tear (object) / swell up / speak / continue.

$\rightarrow$ (He/She) who used to boast with an arrogant attitude continued to speak with tears swelling up.

추운 날씨에도 불구하고 바깥에서 사진를/을 세시간동안 열심히 찍었습니다. Cold / weather / despite / outside / photos (object) / 3 hours during / diligently / took.

$\rightarrow$ Despite cold weather, I (or he or she) took photos outside for 3 hours diligently.

통삼겹살과 김치보쌈으로 푸짐한 저녁를/을 해결하고 숙소로 돌아왔습니다. Bacon and / kimchi wrap with / abundant / dinner (object) / solve and / lodge to / returned.

$\rightarrow$ We returned to our hotel after substantial dinner with bacon and kimchi wrap.

자투리 시간 활용으로 그날 배운 내용를/을 철저히 복습해서 효과가 있었습니 다.

Leftover / time / use / the day / learn / content (object) / perfectly / review / effect / there was.

$\rightarrow$ It was effective to use small chunks of times and review the day's content.

예술적 경지에 오른듯 매력적인 음악를/을 청중에게 흠뻑 들려주고 있습니다. Artistic / level at / reach as if / attractive / music (object) / audience to / profusely / have them listen / -ing.

$\rightarrow$ (The artist) is playing a charming piece of music to audience as if s/he was in epiphany.

아무리 힘들어도 조금만 참고 회사은/는 그만두면 안된다고 했습니다.

No matter how / difficult / a little only / endure and / company (topical) / quit if / don't / said.

$\rightarrow$ S/he said that although it is very difficult, we should be patient and should not quit the company.

올해 가을 앨범에 발표한 이번 노래은/는 괜찮은 것 같은데 인기가 없습니다. This year / autumn / album in / present / this / song (topical) / good / thing / seems but / popularity / lack.

$\rightarrow$ The song that came out in the fall album sounds good to me, but it is not popular.

공부를 열심히 하지는 않았지만 학교은/는 매일 부지런히 다녔습니다.

Study / hard / do / not but / school (topical) / daily / diligently / went.

$\rightarrow$ Although I did not study hard, I went to school diligently everyday. 
진정성을 가지지 못한 얄팍한 변화은/는 오래 지탱하지 못하게 됩니다.

Authenticity / possess / not / shallow / change (topical) / long / last / cannot / become.

$\rightarrow$ Unauthentic, shallow change does not last long.

생후 일년 미만 된 아기의 부모은/는 육아시간을 사용할 수 있습니다.

After birth / 1 year / less than / become / baby's / parents (topical) / nursing time / use / can / (copula).

$\rightarrow$ Parents who have a baby less than a year old can use maternity leave.

상식적으로 회사에서 일을 한 시간는/은 근무시간으로 인정되어야 합니다.

Common sense / workplace at / work / do / time (topical) / office hours / be acknowledge / needs to.

$\rightarrow$ It is a common sense that the hours spent working at the office should be considered working (on-duty) hours.

서양인과 비교해서 동양인의 얼굴는/은 대체로 어려 보이는 경우가 많습니다. Westerner to / compared / Asians' / face (topical) / generally / young / seem / case / prevalent.

$\rightarrow$ Asians tend to look young compared to those of Westerners.

시간이 많이 흘렀지만 일상생활 모습는/은 지금과 다르지 않았던 것 같습니다. Time / much / pass but / daily / life / image (topical) / now with / different / not / thing / appear.

$\rightarrow$ Much time has passed by, but it seems that daily life (in those days) does not seem to be different from that of today.

역사적으로 한국사회에서 교육는/은 아주 중요한 위치를 차지하고 있습니다. Historically / Korean / society in / education (topical) / very / important / status / taken / has.

$\rightarrow$ Education has been very important historically in Korean society.

살을 빼려면 식이요법과 함께 운동는/은 필수로 빼놓을 수 없는 것입니다.

Weight / lose if / diet and / with / exercise (topical) / essentially / miss / can / not / is.

$\rightarrow$ If you want to lose weight, exercise is essential along with diet.

이 영화는 화해와 우리의 존재이/가 갖는 의미를 고찰한 작품입니다.

This / movie / reconciliation and / our / existence (subject) / have / meaning (object) / contemplate / work is.

$\rightarrow$ This movie depicted reconciliation and the meaning of our existence.

조율을 하지 않아 피아노 상태이/가 아주 좋지 않은 것 같습니다.

Tuning / do / not / piano / condition / very / good / not / thing / seems.

$\rightarrow$ Due to lack of tuning, the piano does not appear to be in good condition. 
현대사회에서는 국가간의 관계이/가 복잡할 수 밖에 없습니다.

Modern society in / nation / between / relation (subject) / complex / thing / only / not.

$\rightarrow$ In modern society, it is inevitable that the relations between countries are complex.

연락이 없다가 이른 새벽에 친구이/가 저한테 문자를 보냈습니다.

Contact / was not / early / morning at / friend (subject) / me to / text message / sent.

$\rightarrow$ After no contact, my friend sent me a text message early this morning.

음식점에서 고기를 굽는 맛난 냄새이/가 문밖 길거리까지 솔솔 났습니다.

Restaurant at / meat / grill / delicious / smell (subject) / outside / street / fragrantly / occur.

$\rightarrow$ The smell of meat grilled at the restaurant was apparent outside even in the street.

좋은 일은 많이 하면 할 수록 마음가/이 부자가 되어 아주 뿌듯합니다.

Good / work / many / do if / do / more / mind (subject) / become / very / proud.

$\rightarrow$ I am proud that the more good things I do, the happier I become in my heart.

다음 주 어머님 생신을 맞아 온 가족가/이 음식점에서 모이기로 했습니다.

Next / week / mother-in-law / birthday / celebrate / whole / family (subject) / restaurant at / gather / decided.

$\rightarrow$ The whole family decided to meet at a restaurant for my mother's birthday next week.

머리가 깨끗하게 맑아지고 기분가/이 상쾌해지는 솦속향입니다.

Head / clearly / become clear / mood (subject) / fresh become / forest scent is.

$\rightarrow$ The scent of woods makes us feel alert and refreshed.

얼굴이 빨개지며 수줍어하는 표정가/이 새삼 순진하게 느껴졌습니다.

Face / red become / bashful / expression (subject) / again / innocent / felt.

$\rightarrow$ Her blush and shy expression on her face made me think again that she is innocent.

아동청소년 문학의 특징과 작품가/이 추구하는 세계를 논설했습니다.

Youth / literature's / characteristics and / work (subject) / seeking / world / elaborate.

$\rightarrow(\mathrm{He} / \mathrm{she})$ elaborated on the characteristics of adolescent literature and the world it pursues.

Sentences used in condition 2

경제는 비약적으로 발전했고 정치를/는 이제 비로소 안정을 찾았습니다.

Economy / rapidly / developed / politics (object / topical) / now / finally / stability (object) / recuperated. 
$\rightarrow$ The economy made rapid development and the politics (government) finally became stable.

자연을 닮은 아이로 키우려고 엄마를/는 친자연주의 제품을 구입합니다.

Nature / resemble / child / raise / mother (object / topical) / nature friendly / product / purchase.

$\rightarrow$ The mother purchases eco-friendly products so that her child comes to respect nature.

발표에 따르면 흡연율이 가장 높은 국가를/는 그리스로 나타났습니다.

Report / according to / smoking rate / most / high / country (object / topical) / Greece / (copula).

$\rightarrow$ According to the report, the country with the highest smoking rate was Greece.

자신과 전혀 관계없는 모르는 전화가/는 받지 말고 바로 끊는 것이 좋습니다. Oneself with / never / irrelevant / unknown / phone call (subject / topical) / receive / not and / immediately / hang / up / better.

$\rightarrow$ It is advisable that you should not answer a phone call from an unknown person.

개성이 강한 시대인만큼 나만의 세계가/는 내가 만들어가야 합니다.

Individuality / strong / a time since / my won / world (subject / topical) / I / should make.

$\rightarrow$ I should create a world of mine since it is a time when individuality is valued.

삶을 폭넓게 경험하고자 할 때 문학을/은 좋은 소재를 제공해줍니다.

Life / widely / experience want to / do / when / literature (object / topical) / good / topics / provide.

$\rightarrow$ When you want to have rich life experiences, literature provides good topics.

그의 평안한 임종을 지켜보며 죽음을/은 두려운 것이 아님을 깨달았습니다. His / peaceful / imminent death / watching / death (object / topical) / fearful / thing / not (object) / realized.

$\rightarrow \mathrm{S} /$ he realized that death is not something to fear when s/he watched his peaceful death.

수만명이 다녀간 해운대의 아침을/은 쓰레기로 가득찬 모습입니다.

Tens of 1,000s of people / come by / Haeoondae's / morning (object / topical) / gargage with / filled / image is.

$\rightarrow$ Haeoondae is filled with trash in the morning after tens of thousands of people had come by.

어렸을 때의 생각과는 달리 사랑이/은 귾임없는 노력과 끈기를 필요로 합니다. Childhood / when / thinking with / different from / love (subject / topical) / ceaseless / effort and / patience / needed / is.

$\rightarrow$ Different from one's childhood thinking, love requires continuing effort and patience. 
아무리 사랑한다 하더라도 자식이/은 결국 떠나보내야 하는 존재입니다.

No matter how much / love / despite / children (subject / topical) / eventually / leave / send / -ing / being is.

$\rightarrow$ No matter how much you love your children, you eventually have to let them go.

우리가 사는 소중한 이 땅에 나무를/가 없으면 생태계가 어떻게 될지 궁금합니 다.

We / living / precious / this / earth on / tree (object / subject) / not exist if / ecosystem / how / become / wonder.

$\rightarrow$ I wonder about what would happen to ecosystem if there are no trees on this earth we live.

게시판을 설치하고서는 이런 문제를/가 생긴 것 같아 마음이 답답합니다.

Bulletin board (object) / install / this / problem (object / subject) / transpire / seems / heart / frustrated.

$\rightarrow$ I am frustrated because it seems that this problem has occurred since the installation of a bulletin board.

작년 대통령 선거 결과는 역사를/가 바뀌는 세기의 일대 사건이었습니다.

Last year / presidential / election / result / history (object / subject) / changing / century's / remarkable / event was.

$\rightarrow$ The result of the presidential election last year was a remarkable, history changing event.

홍수처럼 밀려나온 뉴스때문에 하루는/가 다 가도록 허덕이며 쫓아다녔습니 다.

Flood like / gush / come out / news because of / 1 day (topical / subject) / all / pass by / hectically / ran around.

$\rightarrow$ I was swamped with work the whole day due to a lot of news.

아무리 기술이 발전해도 인간에게 언어는/가 없다면 살기 힘들것입니다.

No matter how / technology / develop despite / humans to / language (topical / subject) / not exist if / living / will be difficult.

$\rightarrow$ No matter how advanced technology develops, it will be difficult to live without language.

당신을 최고로 사랑해주는 남편을/이 되도록 매일 매일 노력하겠습니다.

You / the most / loving / husband (object / subject) / become to / daily / daily / strive will.

$\rightarrow$ I will strive everyday to be a husband who loves you dearly.

오늘따라 작은 아이가 자기 이름을/이 마음에 안든다고 투정부렸습니다.

Today particularly / younger / child / oneself / name (object / subject) / mind in / do not like / whined.

$\rightarrow$ My second child was whining particularly today that s/he does not like his/her name. 
풍부한 인력자원을 이용해 대학을/이 기후변화에 앞장서야 합니다.

Plenty / human resource / using / university (object / subject) / climate change / lead / should.

$\rightarrow$ Universities should lead climate change effort using abundant human resources.

자유 뒤에는 반드시 그에 대한 책임은/이 따라오게 되어있음을 자각했습니다. Freedom / behind / certainly / that / about / responsibility (topical / subject) / follow / bound to / realized.

$\rightarrow$ S/he realized that freedom certainly requires responsibility.

몇 년 동안 노력한 결과로 노인은/이 살던 집을 드디어 찾아냈습니다.

Several years for / effort / result as / finally / old man (topical / subject) / having lived / house / found out.

$\rightarrow$ Thanks to years of effort, we finally found the house where the old man used to live.

열악한 환경에서도 개인의 이익보다 사회가/를 위해 일하는 청년입니다.

Inadequate / environment despite / individuals' / benefit rather than / society (subject / object) / for / working / young man is.

$\rightarrow(\mathrm{He})$ is a young man who works for the benefit of society rather than personal desire even in a challenging environment.

동남아에 일주일 여행갔다가 담배가/를 여러 보루 사가지고 들어왔습니다.

East South Asia in / a week / trip / went / tobacco (subject / object) / several / packs about / buy / came back.

$\rightarrow$ I bought several packs of cigarettes from a trip to South East Asia for a week.

험한 골짜기에 이런 웅장한 다리가/를 만들 수 있다는 게 놀랍습니다.

Steep / valley in / this / grant / bridge (subject / object) / build / thing / can / the fact / surprising.

$\rightarrow$ It is surprising that people can build a grand bridge in this steep valley.

언제나 나를 용서해 주는 바다는/를 스케치하며 바다와 이야기하렵니다.

Always / me / forgive / -ing / sea (topical / object) / sketch while / sea with / talk will.

$\rightarrow$ I am going to talk with the ocean while sketching the always forgiving ocean.

세살짜리 딸아이가 엄마 머리는/를 빗어주는 모습은 무척 감동이었습니다.

Three years old / daughter / mom's / hair (topical / object) / brushing / image / very much / touching.

$\rightarrow$ The scene in which a three-year-old daughter was brushing her mom's hair was touching.

인간에 대해 지식을 쌓으려면 인간이/을 직접 대면하는 가장 좋은 방법입니다. Humans / about / knowledge / accumulate if / humans (subject / object) / directly / facing / the / best / method is. 
$\rightarrow$ If you want to be knowledgeable about human beings, the best method is to interact with human beings face to face.

외로운 밤에는 별이 많아지는 까닭이/을 이제야 비로소 알게 되었습니다.

Lonely / night at / star / become numerous / reason (subject / object) / just now / finally / know / came to.

$\rightarrow$ I finally realized the reason why there are more stars at a lonely night.

끊임없이 우리의 마음과 생각이/을 훈련시켜 나가는 게 필요합니다.

Ceaseless / our / mind and / thoughts (subject / object) / training / is / needed.

$\rightarrow$ It is necessary to continuously train our minds and thoughts.

본인의 의사와 관계없이 정든 고향은/을 떠난다는 것은 가슴 아픈 일입니다. Oneself's / intention with / irrelevant / attached / hometown (topical / object) / that / heart / hurting / occasion is.

$\rightarrow$ Leaving one's hometown against one's will is a heartbreaking event.

사회의 여러 조직들이 힘없는 개인은/을 압박하는 것은 비겁합니다.

Society's / several / organizations / helpless / individuals (topical / object) / supress /

- ing (topical) / cowardly is.

$\rightarrow$ It is cowardly for societal organizations to suppress helpless individuals.

\section{References}

Altarriba, J., Kambe, G., Pollatsek, A., \& Rayner, K. (2001). Semantic codes are not used in integrating information across eye fixations in reading: Evidence from fluent Spanish-English bilinguals. Perception \& Psychophysics, 63, 875-890.

Balota, D. A., Pollatsek, A., \& Rayner, K. (1985). The interaction of contextual constraints and parafoveal visual information in reading. Cognitive Psychology, 17, 364-390.

Carlson, G. N., \& Tanenhaus, M. K. (1988). Thematic roles and language comprehension. In W. Wilkins (Ed.), Syntax and semantics (Vol. 21). Thematic relations (pp. 263-300). San Diego, CA: Academic Press.

Drieghe, D., Rayner, K., \& Pollatsek, A. (2008). Mislocated fixations can account for parafoveal-onfoveal effects in eye movements during reading. Quarterly Journal of Experimental Psychology, 61, 1239-1249.

Engbert, R., \& Nuthmann, A. (2008). Self-consistent estimation of mislocated fixations during reading. PLOS ONE, 3(2), e1534.

Engbert, R., Nuthmann, A., Richter, E., \& Kliegl, R. (2005). SWIFT: A dynamical model of saccade generation during reading. Psychological Review, 112, 777-813.

Hagstrom, P., \& Rhee, J. (1997). Differences between Korean and Japanese processing overload. Journal of Psycholinguistic Research, 26, 189-206.

Hohenstein, S., Laubrock, J., \& Kliegl, R. (2010). Semantic preview benefit during eye movements in reading: A parafoveal fast-priming study. Journal of Experimental Psychology: Learning, Memory, and Cognition, 36, 1150-1170.

Inhoff, A. W. (1990). Integrating information across eye fixations in reading: The role of letter and word units. Acta Psychologica, 73, 281-297.

Inhoff, A. W., \& Radach, R. (1998). Definition and computation of oculomotor measures in the study of cognitive processes. In G. Underwood (Ed.), Eye guidance in reading and scene perception (pp. 29-54). Oxford: Else. 
Inhoff, A. W., \& Weger, U. (2003). Advancing the methodological middle ground. In J. Hyönä, R. Radach, \& H. Deubel (Eds.), The mind's eye: Cognitive and applied aspects of eye movements (pp. 335-344). Oxford: Elsevier.

Kim, Y. (1999). The effects of case marking information on Korean sentence processing. Language and cognitive processes, 14, 687-714.

Kim, Y.-S. (2007). Phonological awareness and literacy skills in Korean: An examination of the unique role of body-coda units. Applied Psycholinguistics, 28, 67-93.

Kim, Y.-S. (2011). Considering linguistic and orthographic features in early literacy acquisition: Evidence from Korean. Contemporary Educational Psychology, 36, 177-189.

Koh, S. (1997). The resolution of the dative NP ambiguity in Korean. Journal of Psycholinguistic Research, 26, 265-273.

Lee, I., \& Ramsey, R. (2000). The Korean language. Albany, NY: State University of New York Press.

Lee, S. S., Lee, K.-D., Nam, K.-S., Chung, C.-S., Lee, I.-K., \& Choi, Y.-C. (1991). Development of a corpus of contemporary Korean for compiling a lexicographical database. Seoul, Korea: Korean Dictionary Compilation Board of Yonsei University.

Lee, H.-W., Rayner, K., \& Pollatsek, A. (1999). The time course of phonological, semantic, and orthographic coding in reading: Evidence from the fast-priming technique. Psychonomic Bulletin \& Review, 6, 624-634.

Liu, W., Inhoff, A. W., Ye, Y., \& Wu, C. (2002). Use of parafoveal visible characters during the reading of Chinese sentences. Journal of Experimental Psychology: Human Perception and Performance, 28, 1213-1227.

MacDonald, M. C., Perlmutter, N. J., \& Seidenberg, M. S. (1994). Lexical nature of syntactic ambiguity resolution. Psychological Review, 101, 676-703.

Mazuka, R., \& Lust, B. (1990). On parameter-setting and parsing: Predictions for acquisition. In L. Frazier \& J. de Villiers (Eds.), Language processing and acquisition (pp. 163-206). Dordrecht: Kluwer.

McConkie, G. W. (1981). Evaluating and reporting data quality in eye movement research. Behavior Research Methods \& Instrumentation, 13, 97-106.

Pollatsek, A., Lesch, M., Morris, R. K., \& Rayner, K. (1992). Phonological codes are used in integrating information across saccades in word identification and reading. Journal of Experimental Psychology: Human Perception and Performance, 18, 148-162.

Radach, R., \& Kennedy, A. (2004). Theoretical perspectives on eye movements in reading: Past controversies, current deficits and an agenda for future research. European Journal of Cognitive Psychology, 16, 3-26.

Radach, R., Reilly, R., \& Inhoff, A. W. (2007). Models of oculomotor control in reading: Towards a theoretical foundation of current debates. In R. van Gompel, M. Fischer, W. Murray, \& R. Hill (Eds.), Eye movements: A window on mind and brain. Elsevier: Oxford.

Rayner, K. (1975). The perceptual span and peripheral cues in reading. Cognitive Psychology, 7, 65-81.

Rayner, K. (1998). Eye movements in reading and information processing: 20 years of research. Psychological Bulletin, 124, 372-422.

Rayner, K., Well, A. D., Pollatsek, A., \& Bertera, J. H. (1982). The availability of useful information to the right of fixation in reading. Perception \& Psychophysics, 31, 537-550.

Rayner, K., Balota, D. A., \& Pollatsek, A. (1986). Against parafoveal semantic preprocessing during eye fixations in reading. Canadian Journal of Psychology, 40, 473-483.

Rayner, K., White, S. J., Kambe, G., Miller, B., \& Liversedge, S. P. (2003). On the processing of meaning from parafoveal vision during eye fixations in reading. In J. Hyönä, R. Radach, \& H. Deubel (Eds.), The mind's eye: Cognitive and applied aspects of eye movement research (pp. 213-234). Amsterdam: Elsevier.

Reichle, E. D., Pollatsek, A., Fisher, D. L., \& Rayner, K. (1998). Toward a model of eye movement control in reading. Psychological Review, 105, 125-157.

Reichle, E. D., Rayner, K., \& Pollatsek, A. (2003). The E-Z reader model of eye movement control in reading: Comparisons to other models. Behavioral and Brain Sciences, 26, 446-526.

Reilly, R., \& Radach, R. (2006). Some empirical tests of an interactive activation model of eye movement control in reading. Cognitive Systems Research, 7, 34-55.

Sohn, H.-M. (1999). The Korean language. Cambridge, UK: Cambridge University Press.

Suh, S. (1994). The syntax of Korean and its implications for parsing theory. Unpublished doctoral dissertation, University of Maryland. 
Uehara, K. (1997). Judgments of processing load in Japanese: The effect of NP-ga sequences. Journal of Psycholinguistic Research, 26, 255-263.

Yan, M., Richter, E., Shu, H., \& Kliegl, R. (2009). Readers of Chinese extract semantic information from parafoveal words. Psychonomic Bulletin \& Review, 16, 561-566.

Yan, M., Risse, S., Zhou, X., \& Kliegl, R. (in press). Preview fixation duration modulates identical and semantic preview benefit in Chinese reading. Reading and Writing: An Interdisciplinary Journal.

Yan, M., Zhou, W., Shu, H., \& Kliegl, R. (in press). Lexical and sub-lexical semantic preview benefits in Chinese reading. Journal of Experimental Psychology: Learning, Memory, and Cognition.

Yang, J., Wang, S., Tong, X., \& Rayner, K. (in press). Semantic and plausibility effects on preview benefit during eye fixations in Chinese reading. Reading and Writing: An Interdisciplinary Journal.

Yen, M.-H., Tzeng, O. J.-L., Radach, R., \& Tsai, J.-L. (2011). Usage of statistical cues for word boundary in reading Chinese sentences. Reading and Writing: An interdisciplinary Journal (in press). 